\title{
Idyllic Ruralities, Displacement and Changing Forms of Gentrification in Rural Hertfordshire, England
}

\author{
Martin Phillips \\ University of Leicester. School of Geography, Geology and Environment \\ martin.phillips@le.ac.uk
}

\section{Darren Smith}

Loughborough University. Geography and Environment, School of Social Sciences and Humanities

D.P.Smith@lboro.ac.uk

\author{
Hannah Brooking \\ Mara Duer \\ University of Leicester. School of Geography, Geology and Environment \\ hbrooking15@gmail.com \\ mara.duer@gmail.com
}

Received: May 2019

Accepted: December 2019

Published: March 2020

\begin{abstract}
This paper considers the significance of representations of rurality and displacement in relation to the concept of rural gentrification. Studies of rural gentrification have often drawn upon notions of the rural idyll, but have often neglected to consider the presence, or not, of displacement. It has been argued that this lack of attention reflects an absence of displacement connected with middle class in-migration, particularly in early decades of counterurbanisation. This paper aims to examine these arguments drawing on the research publications and archived materials stemming from a study by Ray Pahl of four villages in the English county of Hertfordshire in the early 1960s, alongside material generated from a questionnaire survey conducted in three of these villages. The research demonstrates continuities in processes of gentrification and displacement between the two studies, as well as the emergence of new forms of gentrification and the operation of diverse forms of displacement.
\end{abstract}

Keywords: rural gentrification; rural idyll; displacement; Ray Pahl; Hertfordshire 
Resum. Ruralitats idill.liques, desplaçaments i formes de gentrificació al Hertfordshire rural, Anglaterra

Aquest article estudia la importància de les representacions de la ruralitat i del desplaçament en relació amb el concepte de gentrificació rural. Els estudis de gentrificació rural sovint s'han basat en nocions de l'idil.li rural, però també han descuidat la consideració de la presència o no del desplaçament. S'ha argumentat que aquesta falta d'atenció reflecteix l'absència de desplaçaments relacionats amb la migració de la classe mitjana, particularment a les primeres dècades de la contraurbanització. Aquest article té com a objectiu examinar aquests arguments basant-se en les recerques publicades i en els materials d'arxiu derivats d'un estudi de Ray Pahl de quatre pobles al comtat anglès d'Hertfordshire a principis dels anys seixanta, juntament amb el material generat a partir d'un qüestionari d'enquesta realitzada en tres d'aquests pobles. La investigació demostra continuïtat en els processos de gentrificació i desplaçament entre els dos estudis, així com l'aparició de noves formes de gentrificació i el funcionament de diverses formes de desplaçament.

Paraules clau: gentrificació rural; idil.li rural; desplaçament; Ray Pahl; Hertfordshire

Resumen. Ruralidades idílicas, desplazamientos y formas cambiantes de gentrificación en las zonas rurales de Hertfordshire, Inglaterra

Este documento estudia la importancia de las representaciones de la ruralidad y el desplazamiento en relación con el concepto de gentrificación rural. Los estudios de gentrificación rural a menudo se han basado en nociones del idilio rural, pero también se han olvidado de considerar la presencia, o no, del desplazamiento. Se ha argumentado que esta falta de atención refleja la ausencia de desplazamientos relacionados con la inmigración de clase media, particularmente en las primeras décadas de la contraurbanización. Este documento pretende examinar estos argumentos a partir de las investigaciones publicadas y de los materiales de archivo de un estudio realizado por Ray Pahl de cuatro pueblos en el condado inglés de Hertfordshire a principios de la década de 1960, junto con el material generado a partir de una encuesta realizada en tres de estos pueblos. La investigación demuestra continuidades en los procesos de gentrificación y desplazamiento entre los dos estudios, así como la aparición de nuevas formas de gentrificación y el funcionamiento de diversas formas de desplazamiento.

Palabras clave: gentrificación rural; idilio rural; desplazamiento; Ray Pahl; Hertfordshire

Résumé. Ruralités idylliques, déplacement et formes changeantes de gentrification dans le Hertfordshire rural, Angleterre

Cet article examine l'importance des représentations de la ruralité et du déplacement par rapport au concept de gentrification rurale. Les études de gentrification rurale ont souvent fait appel à la notion d'idylle rurale, mais elles ont souvent négligé d'envisager la présence ou l'absence de déplacement. On a argumenté que ce manque d'attention reflétait une absence de déplacement lié à l'immigration de la classe moyenne, en particulier au cours des premières décennies de contre-urbanisation. Cet article vise à examiner ces arguments en s'appuyant sur les publications de recherche et les documents d'archive issus d'une étude réalisée par Ray Pahl sur quatre villages du pays anglais du Hertfordshire au début des années 1960, ainsi que sur des éléments provenant d’une enquête par questionnaire menée dans trois de ces villages. Les recherches démontrent la continuité des processus de gentrification et de déplacement entre les deux études, ainsi que l'émergence de nouvelles formes de gentrification et le fonctionnement de diverses formes de déplacement.

Mots-clés: gentrification rurale; idylle rurale; déplacement; Ray Pahl; Hertfordshire 


\section{Summary}

1. Introduction

2. Connecting rural gentrification, the rural idyll and displacement

3. Rural Hertfordshire and the study of rural gentrification: the rationale for a case study

4. Class and idyllic ruralities in Hertfordshire villages in the early 1960 s
5. Contemporary gentrification in rural Hertfordshire

6. Displacement in the past and present Hertfordshire countryside

7. Displacement forms in the contemporary gentrified countryside

8. Conclusion

Bibliographical references

\section{Introduction}

Idyllic conceptions of rurality have figured prominently in accounts of European rural space and migration to rural areas, as well as associated processes such as counterbanisation and rural gentrification (e.g. Halfacree, 1994; Hjort and Malmberg, 2006; Vepsäläinen and Pitkänen, 2010; Solana-Solana, 2010; Benson and Osbaldiston, 2014; Cortes-Vazquez, 2017). Several of these works make reference to the writings of the British sociologist Ray Pahl that stemmed from research he conducted in villages in the English county of Hertfordshire in the early 1960s. This work included claims that a 'business and professional' middle class were moving into these settlements with a mental imagery of rural life, or a "village-in-the-mind" (Pahl, 1966: 305), centred around ideas of "a meaningful community and [...] the cosiness of village life", while omitting any reference to people "suffering any [...] deprivations" (Pahl, 1964: 9). Subsequent studies have reproduced these arguments, with Key (2014: 251) recently arguing that idyllic rural imagery centred around notions of community and "beauty, order and peacefulness" have "contributed to the gentrification of much of rural Britain".

Despite such claims as to the significance of idyllic notions of rurality, there have recently been signs of re-appraisals of their significance (e.g. Woodward, 1996; Bell, 1997; Phillips et al., 2001; Bijker and Haartsen, 2012; van Dam et al., 2002; Solana-Solana, 2010; da Silva et al., 2016; Shucksmith, 2016). Many of these recent critiques have focused on highlighting supplemental elements of rural representations, such as diversity in the constituents of idyllic constructions or the presence of non-idyllic as well as idyllic signifiers of rurality. These critiques stand in some contrast to a slightly earlier line of criticism that focused on the omissions established within idyllic representations, and how these might be contrasted with constructions of "the realities of rural environments" (James, 1991: 28; see also Bradley et al., 1986; McLaughlin, 1986). These earlier criticisms, which can be seen as central to the notions of a 'critical' perspective on rural culture that emerged from the late 1970s (see Newby and Buttel, 1980; Phillips, 1994, 1998), exhibit clear parallels with Pahl's commentaries on the 'village-in-the-mind' of middle-class in-migrants, 
which presented these as occluding any recognition of the deprivations of rural living that were central to the experiences of working-class residents within these villages. However, it can be objected that the images of the realities of rural life presented by Pahl and others to criticise the imagery of rural life present within the 'village-in-the-mind' of middle-class residents were themselves as equally representational constructs as the idyllic images they were being contrasted with. As discussed in Phillips et al. (2001: 4), such objections led to rural studies moving, to a degree, "against such 'critical' interpretations of rural imagery" in favour of a focus on "describing their cultural composition", or as it is more widely described, their 'cultural construction' (e.g. Rye, 2006; Horton, 2008; Peeren and Souch, 2019). This having been said, there has also been a continuing concern about recognising the impacts of these representations, and the processes of their cultural construction, on the lives of people living in rural places (see Phillips et al., 2001; Cloke, 2006; Woods, 2010; Kerrigan, 2018).

In the current paper we wish to consider representations of rurality and the lived experiences of people living in rural areas in relation to the concept of rural gentrification, and most specifically, with regard to the notion of displacement. The paper will provide evidence of both the presence of idyllic representations of rurality within the formation of rural gentrification and the emergence of processes of social displacement. It will be argued that displacement has been a relatively neglected aspect of studies of gentrification in rural areas and the paper will specifically consider the relevance of Marcuse's (1985) identification of four different forms of displacement to understanding social changes in rural space. In exploring the connections between idyllic and experiential constructions of rurality and processes of rural gentrification, the paper will draw upon contemporary research conducted not only in the same county of England that formed the focus of Pahl's research, but on three of the villages where he conducted his research. The contemporary research is part of a wider comparative study of rural gentrification, ${ }^{1}$ but in this paper it is connected not only to the publications of Pahl, but also to unpublished documents produced as part of his research within these villages. The next section of the paper will expand on the theoretical rationale for the study of idyllic constructions of rurality, rural gentrification and displacement. After this, the rationale for focusing on rural Hertfordshire and the materials and methods employed in the research will be outlined. Subsequent sections of the paper explore the relations between class and idyllic ruralities in the period of Pahl's original study, before examining contemporary forms of gentrification, and then the varieties of displacement that might accompany rural gentrification across both periods. The paper ends by considering the significance of diverse forms of gentrification on displacement.

1. This research was supported by the Economic and Social Research Council [grant number ES/L016702/1]. It was conducted as part of the International Rural Gentrification (iRGENT) project, details of which are available at <www.i-rgent.com $>$. 


\section{Connecting rural gentrification, the rural idyll and displacement}

Whilst the term gentrification is widely associated with urban areas, it has from at least the late 1970s been also applied to rural contexts (e.g. Cloke, 1979; Parsons, 1980). Gentrification has been described as a "congested and contested concept" (Phillips, 2005: 477), with there being a range of contrasting understandings of the concept advanced, and an often quite heated debate both as to their meaning and relative value and, indeed, the overall value of the concept itself (e.g. see Hamnett, 1991, 1992, 2009, 2010; Smith, 1992; Slater, 2006, 2008, 2009, 2010). There have also been calls to emphasise the distinctiveness of processes of gentrification within rural and urban localities (e.g. Ley, 1996; Smith and Phillips, 2001), although there have also been claims that apparent differences should be viewed as contingent features that effectively mask similarities in the processes that are necessarily involved in all instances of gentrification (e.g. Clark, 2005). In both urban and rural contexts, gentrification has, for instance, often been viewed as involving "the 'refurbishment', or doing up, of properties in an area and associated changes in its social composition" (Phillips, 2005: 477-78), linked to the in-migration of middle-class residents. Furthermore, in both urban and rural studies there has also been an increasing tendency to extend its definition to include new build developments as well as the refurbishment of properties (e.g. Smith, 2002; Davidson and Lees, 2005, 2010; Lees et al., 2008; Phillips, 2010; Nelson and Hines, 2018).

While arguments have been raised about the similarities of gentrification in rural and urban areas, claims relating to their difference have often centred around the significance of idyllic constructions of rurality within processes of gentrification occurring in the countryside. Smith and Phillips (2001: 457-58), for example, claimed that a desire to live in a "'green' residential space" and in places that accord to "idyllic middle class images of the rural", stand "in contrast to the 'urban' qualities which attract in-migrant counterparts in urban locations". Such arguments have close connections with studies of counterurbanisation, where researchers such as Halfacree have long stressed how idyllic notions of rurality can motivate migrational movement (e.g. Halfacree, 1994, 1995; Halfacree and Rivera, 2012). However, Halfacree (2011: 619) has also argued that these idylls may, firstly, have "a very problematic connection to 'actually existing' twenty-first century rurality", and, secondly, act subsequent to the moment of migration to establish points of connection to what he claims is "a more "natural', grounded "outside" that offers "an alternative expression of the everyday to that encapsulated by urban capitalist life" (p. 620), or as he was later to remark, constitute "expressions of everyday resistance embodied within rural gentrification" (Halfacree, 2018: 29).

Halfacree's first point links back to criticisms about the omissions involved in establishing idyllic representations of rural living, whilst his second argument about rural idylls and rural gentrification can be seen to reflect his more general desire to unearth 'radical ruralities' that can challenge "the predomi- 
nant scripting of the countryside" (Halfacree, 2007: 126). This argument has interesting parallels with connections drawn between urban gentrification and notions of an 'emancipatory city'. As outlined in Lees (2000), this latter notion was implicit in the work of people such as Ley (1996) and Butler (1997) that focused on the residential choices and agency of middle-class gentrifiers, but became more explicit in the work of Caulfield who argued that gentrification represented an effort by people to "resist institutionalized patterns of dominance and suppressed possibility" (Caulfield, 1994: xiii; see also Caulfield, 1992). The emergence of gentrification, Caulfield argued, was partly rooted in a "resistance among a specific segment of city-dwellers to certain key aspects of the construction of contemporary urban space (particularly modernism and suburbanism as these have been refracted through the interests of capital and the state)", and an impulse to create "a more humane", or "emancipatory" city form (Caulfield, 1994: 104).

The arguments of Caulfield resonate strongly with Halfacree's contention that rural gentrification might be viewed as a means to both cope with, and in some instances to challenge, the "life course demands posed by 21 st-century neo-liberal existence" (Halfacree, 2018: 29). Halfacree (2010: 250), for instance, argues that counterurban movements to the countryside may be seen as "immanent and implicit" responses to the capitalistic character of contemporary urban life, involving elements of flight, insulation and negation. Idyllic representations of the countryside, he argues, present the countryside as a place to escape, or resist, or be renewed to act in, contemporary capitalist society. However, it is also important to note that the arguments of Caulfield have been subjected to considerable criticism, with Lees (2000: 393) claiming that they constitute "a rose-tinted vision as much as a description of contemporary urban experience", whilst Slater (2004), in a more empirical examination, concluded that there was little evidence of positive change associated with subsequent periods of gentrification in Toronto. Later, Slater (2006: 741) argued that the work of Caulfield acted to 'sugarcoat' the processes of inner city refurbishment by "steering the understanding of gentrification away from the negative effects it produces". As such, it constituted one instance of a wider trend that Slater (2006: 737) identified as "the 'eviction' of critical perspectives" from the study of gentrification. Key to these perspectives, Slater claimed, was recognition of displacement, which he argued was not only a central component of the original definition and early studies of gentrification, but should also be viewed as "vital to an understanding of gentrification, in terms of retaining definitional coherence and of retaining a critical perspective" (Slater, 2006: 748).

Just as Caulfield's arguments about urban gentrification have been subject to criticism, Halfacree's arguments concerning the radical potentialities of rural gentrification stand, as he himself acknowledges (Halfacree, 2011), in clear tension with many other studies, which arguably enact some of the characteristics ascribed by Slater to 'critical' interpretations of gentrification. Gallent (2011: 612), for example, emphasised connections between rural idylls and processes of exclusion, arguing that the valuation of rural idylls "by those 
with money" and "who are able to exercise political power through local and parish councils" leads to a NIMBYism whereby rural gentrifiers raise "a metaphorical drawbridge against those who might introduce change, either through development or their mere presence". Use of the term drawbridge was indeed explicitly recognised by Halfacree (2010) as an 'encapsulation' of a predominant reading of insulationist interpretations of rurality as centred around the protection of spaces whose idyllic characteristics are seen to be under threat from mainstream urbanised capitalist society. Whilst keen to promote different readings that reveal moments in everyday life where people express some resistance to capitalised logics of social life, Halfacree (2010: 255) recognised that these enactments of rurality contain strong elements of "class reproduction" and "consequent [...] social exclusion".

This paper seeks to contribute to debates over idyllic constructions of rurality and the emancipatory and exclusionary aspects of gentrification through consideration of both the role that idyllic constructions of rural spaces play within rural gentrification and its connections to forms of displacement. In particular, the paper will examine the significance of Marcuse's (1985) identification of four distinct forms of displacement - direct last-resident displacement, direct chain displacement, exclusionary displacement and displacement pressure - for understanding the impacts of rural gentrification. Marcuse's work on displacement has been viewed as "a beacon guiding research on gentrification-induced displacement" (Elliott-Cooper et al., 2019:2) and has played a prominent role in Slater's arguments about the significance of displacement within critical conceptualisations of gentrification. Indeed, Slater (2009: 293) argues that Marcuse's arguments over displacement have frequently been "conveniently missed" in "scholarly, journalistic, policy and planning" accounts of gentrification that construct it as some form of benign or positive change. Whilst Marcuse's identification of distinct forms of displacement is advanced in relation to the study of urban gentrification, in this paper we seek to connect them into the study of rural gentrification and consideration of the significance of idyllic ruralities as promoted in the work of people such as Pahl and Halfacree. These two rural researchers have sought, albeit in different ways, to highlight the significance of idyllic representations of rurality whilst enacting some critical concern over their significance in relation to the formation of social differences in access to rural space and the formation of rural lives. This latter concern we contend connects closely to critical conceptions of gentrification which have, at least in an urban context, emphasised the significance of examining gentrification with reference to the presence of some form of displacement. In the present paper we wish to explore the significance of displacement within processes of rural gentrification which may also draw strongly upon idyllic constructions of rurality. In undertaking this, we wish to quite directly focus on the research of Pahl, who, as mentioned in the introduction, developed his ideas about the significance of representations of rurality and rural life within a study of villages in Hertfordshire, England. As outlined in the following section, this paper will continue to explore these 
ideas through the concepts of rural idyll, rural gentrification and displacement by focusing quite directly on three of the villages where Pahl conducted his initial empirical research.

\section{Rural Hertfordshire and the study of rural gentrification: the rationale for a case study}

As part of a comparative study of contemporary rural gentrification in the UK, France and the USA (see Phillips and Smith, 2018a), five case study areas were identified for detailed research (Figure 1), with one location being the local authority districts of North and East Hertfordshire in the South East of England. These two Districts were explicitly chosen because they had been identified as locations experiencing middle-class in-migration and workingclass 'displacement' in the early 1960s when Pahl undertook research in four villages that lay within their bounds (see Figure 2 and Pahl, 1964, 1965a, 1965b, 2008b).

Pahl did not use the term gentrification in his rural research, and in some of his other work appears quite hostile to the concept (e.g. Pahl, 2008a), but his study of Hertfordshire villages is widely seen to have laid the foundations for the study of rural gentrification that emerged a few decades later. Paris (2008: 299), for example, has argued that Pahl's (1965b) study of Urbs in Rure

Figure 1. The English case study districts of the International Rural Gentrification (iRGENT) project

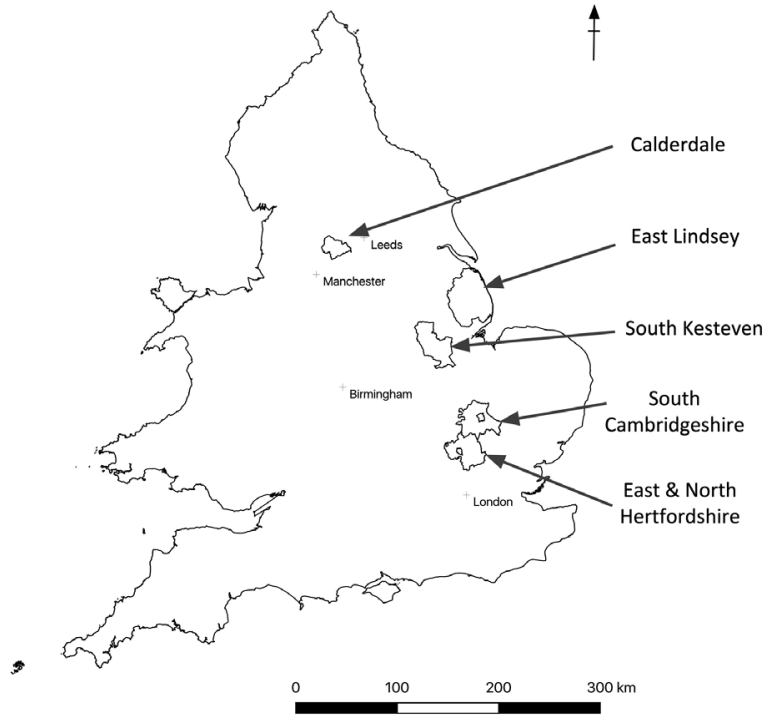

Source: The authors; contains National Statistics data () Crown copyright and database right [2019] and OS data $\odot$ Crown copyright [and database right] (2019). 
Figure 2. The Hertfordshire villages studied by Pahl

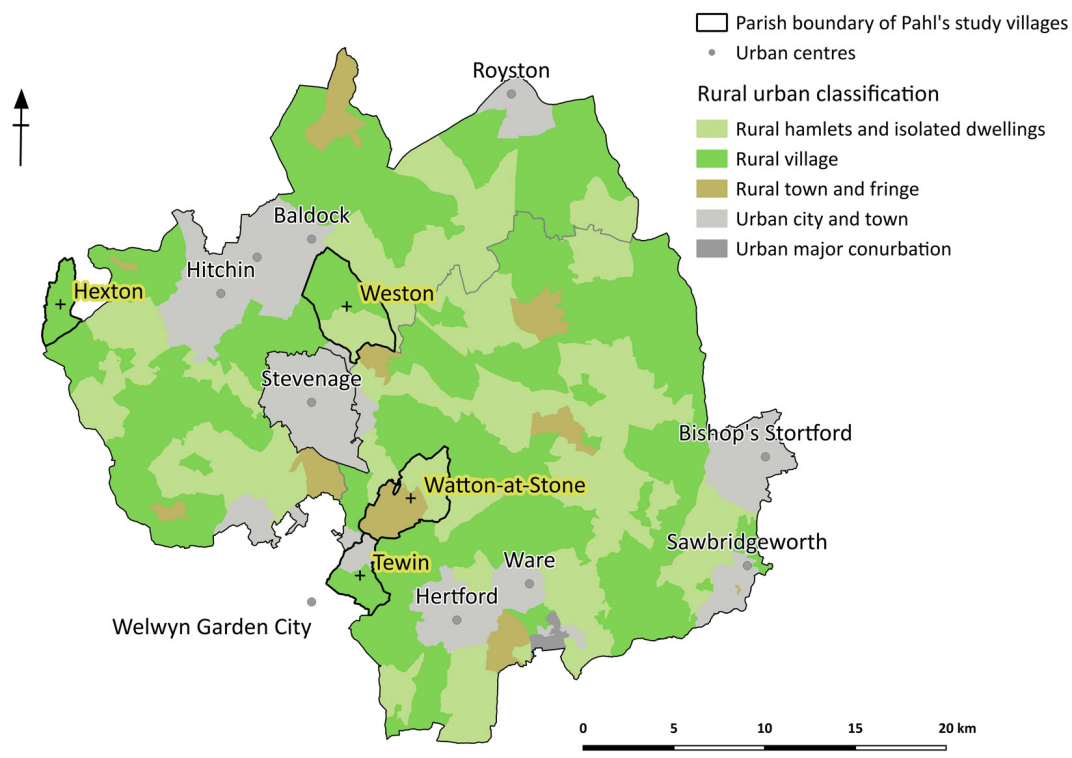

Sources: Based on Rural Urban Classification (2011) of Output Areas in England and Wales, contains National Statistics data (C) Crown copyright and database right [2012] and OS data (C) Crown copyright [and database right] (2012).

described the "processes of neighbourhood displacement, known as gentrification", detailing "the bringing of urban people and incomes into what had been rural settlements". Given this, and the archiving of the questionnaire surveys that Pahl had conducted (Pahl, 2018), use of Hertfordshire as a case study area facilitates temporal as well as spatial comparisons, specifically enabling an investigation of whether there have been any transformations in gentrification processes over the course of the last half century.

Subsequent to this selection, Halfacree's (2018) commentary on rural gentrification was published. This not only stressed the significance of idyllic notions of rurality as a potential motivational driver for middle class migration to the countryside and raised questions concerning the potential presence of resistance to capitalised ways of living within processes of gentrification as outlined in the preceding section, but also used Pahl's study of rural Hertfordshire to explain a reticence to apply the concept of gentrification to the rising middle class presence within the British countryside. Halfacree (2018: 27) argued that Pahl's Hertfordshire study did not present "any clear suggestion of gentrification occurring in terms of the explicit class-based displacement of 'working class quarters [...] invaded by the middle classes' (Glass, 1964: xviii)". More generally, Halfacree suggested that the rising middle class presence in the British countryside might be viewed, at least in the period in which Pahl was 
writing, as largely a process of "repopulation of an already depopulated and still depopulating countryside", and, as such, a "(re)filling of "empty spaces' rather than (immediately) displacing the working class" (Halfacree, 2018: 28).

Such arguments gave a further rationale to the study of Hertfordshire, and provided the impetus for this paper's specific focus on exploring not only the significance of idyllic representations of rurality on social classed migration to the countryside, but also considering whether there is evidence of displacement associated with this migration. To develop this analysis, the paper makes use of material derived from a personally administered questionnaire survey of 232 adult residents carried out in three of the villages studied by Pahl, as well as published material from Pahl's earlier study (e.g. Pahl, 1964, 1965a, $1965 \mathrm{~b}, 1966,2005,2008 \mathrm{~b}$ ) and extracts from the questionnaires generated by Pahl and a small team of co-workers (Pahl, 2018). It was decided to focus on just three of the villages because, as shown in Figures 2 and 3, the other location, Watton-at-Stone, had seen large population increases soon after Pahl conducted his study and is now officially classified as 'rural town and fringe', rather than rural. Our research also made extensive use of UK Census data,

Figure 3. Population change in Pahl's Hertfordshire study villages, 1901-2011
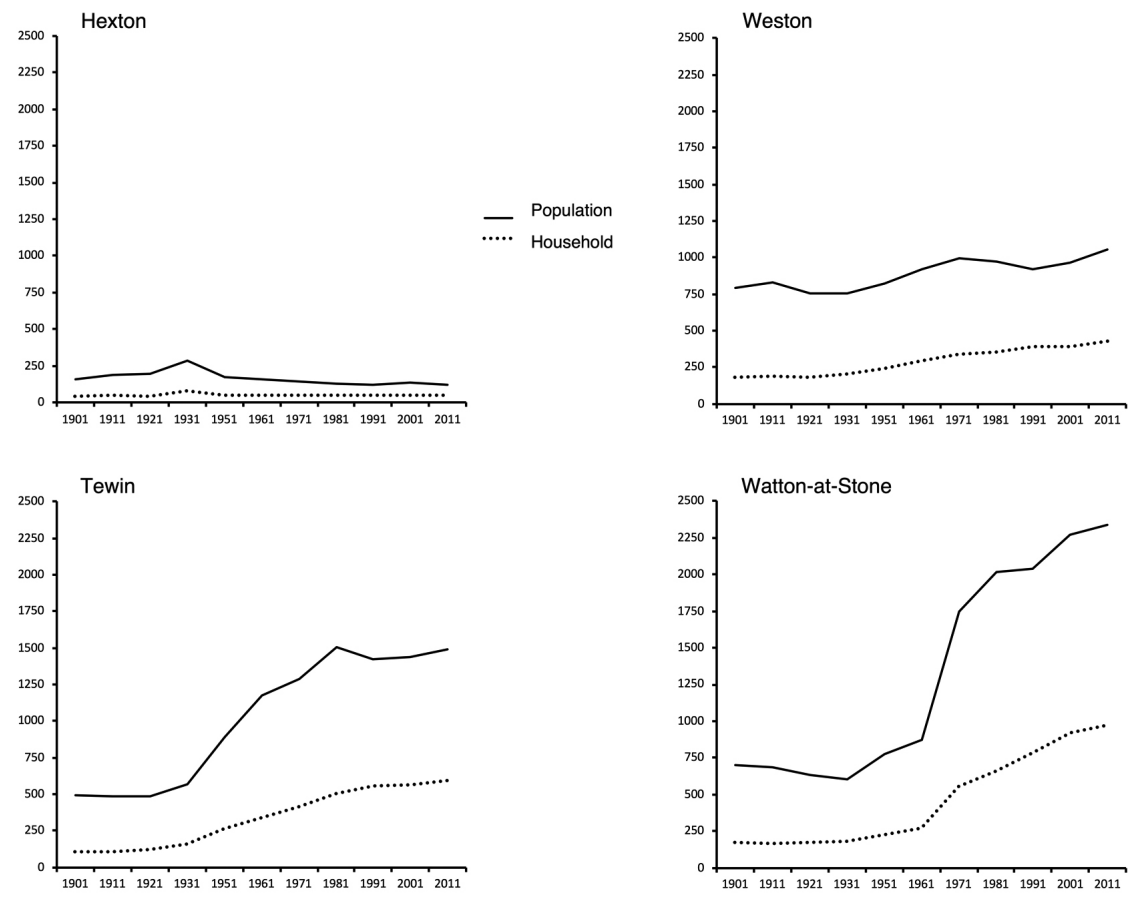

Sources: Based on data from UK Census Reports 1901-1961, accessed via <http://www.visionofbritain. org.uk>; UK Census Small Area Statistics 1971-2001 accessed via <http://casweb.ukdataservice.ac.uk>; UK 2011 Census Output Areas and Small Areas 2011 accessed via <http://infusecp.mimas.ac.uk>. 
some elements of which are used in this paper (for more details, see Smith et al., 2018, 2019). Whilst questionnaires are often viewed as instruments of quantitative research, as McGuirk and O'Neill (2016) have observed, they have long been used to generate both quantitative and qualitative data, a feature which prompts them to identify them as a form of mixed-method research. They further add that the use of open questions within a questionnaire holds a "potential to yield the in-depth responses which match the aspiration of qualitative research" (McGuirk and O'Neill, 2016: 247), and the questionnaire developed for our study involved an extensive set of such questions, alongside some closed questions. Use was also made of visual stimuli, such as reproductions of landscape paintings and photographs of landscapes, buildings and housing interiors to foster interest and engagement over issues such as landscape perception and cultural taste. The questionnaires were administered through face-to-face interviewing, which enabled probing, clarifying and supplementary questions to be asked along the lines of semi-structured interviewing. All residential properties in the three study villages were leafleted with an outline of the project and then their residents approached to see if they were willing to participate in the survey. Overall responses were generated equivalent to just under 17 percent of the households recorded as residing in the three villages in the 2011 Census. The questionnaire interviews were generally audio recorded and transcribed, as well as notes recorded on the questionnaire, with the responses to the open questions then being analysed through the use of NVivo.

\section{Class and idyllic ruralities in Hertfordshire villages in the early $1960 \mathrm{~s}$}

Pahl's study of Hertfordshire villages conducted in the early 1960s emphasised the arrival of middle-class residents into rural areas in proximity to London, a focus that connected to later rural studies framed through use of the concept of counterurbanisation and, as noted by Paris (2008), rural gentrification. As outlined in the introduction, Pahl's studies also promoted ideas of the rural idyll via the concept of a "village-in-the-mind" (Pahl, 1966: 305), and set up the notion that this conception of rurality contrasted with the views of working-class residents, who, he argued, were experientially immersed in the deprivations of rural life and a localised environment.

Pahl's identification of polarisation of consciousness between a middle class idyll and a localised working class 'anti-idyll' has been widely reproduced, albeit in ways that often overlook some lines of argument within his work (Cloke and Thrift, 1987), including Pahl's (1966) identification of a series of other forms of differentiation, both in terms of the groups inhabiting rural space and their spatial imaginaries (see Table 1). Taken together, these differentiations highlighted incomer/local and class differences, although did not map them as directly together as subsequent studies have often assumed. So, for example, Pahl differentiated middle class 'salariats' into 'localist cosmopolitans' for whom 'local roots' and a sense of belonging to a place were of considerable importance, and a 'non-localist middle class' who were 
highly mobile and did not seek to connect to any specific location. He also suggested that incomers were not exclusively middle class, but also included 'urban workers with limited capital'. Furthermore, whilst he later remarked (Pahl, 2005: 625-626) that he had failed to recognise change within the working class, and particularly the significance of working-class residents commuting out of the villages to take advantage of large wage differentials that were emerging in the 1960s between agriculture and manufacturing, he did in some work differentiate 'rural working-class commuters' from the other working class groups of 'urban workers with limited capital' and 'traditional ruralites'.

Pahl (2005: 627) has argued that his neglect of change within the rural working class of Hertfordshire reflected his experiential distance from "working-class agricultural villages", while his recognition of the middle-class "village-in-the-mind' was a reflection of his "greater cultural affinities with the middle-class newcomers". These arguments have interesting resonances with Savage's (2010) discussion of Pahl, which identifies him as a key exponent of a 'technical modernism' that was infusing not only the conduct of social science but also the class structure of industrial capitalist countries more generally, through the emergence of a technocratic and managerial middle class. Whilst Pahl wrote in a very generalised, and by his own admission rather approving way, of an incoming middle-class, examination of the questionnaires completed within his study reveals that many of the middle class he records as having very positive, even idyllic, views about the village into which they had moved, worked in technical and managerial occupations:

Obliged to move from Cheshire ICI works. Didn't want to move but now like it more. Think it's marvellous. Lived in Cheshire 8 years, very deadly and provincial: social life limited to family. People here friendly and sensible [...] If promotion was offered answer 'No'. Very happy not to move. (Research chemist)

Wanted to get out into the country. Obliged to go other side [of] greenbelt. Found the plot and land available when looking. (Technical manager, electrical engineering)

Very pleasant and not too developed with reasonable access (accepting the need for car) to nearby towns. Knew no one during five years at Ruislip, whereas already know lots of people. (Aeronautical engineer)

The presence of technical and managerial workers in Hertfordshire villages should not be viewed as surprising given that, as Hoggart (2005) has detailed, areas around London experienced a significant expansion of light manufacturing in the period pre- and post- the Second World War, linked to the emergence of new markets in household and consumer goods and considerable investment in defence. Pahl's experiential proximity to the arrival of a mobile 'salariat' of a modernising technical workers and industrial managers 
Table 1. Pahl's differentiations of rural residential groups

\begin{tabular}{lll}
\hline Residential Group & $\begin{array}{c}\text { Implied Social } \\
\text { Class Position }\end{array}$ & Spatial positionings and imaginaries \\
\hline Large Property Owners & Aristocratic & Localised \& international \\
\hline Salariat & Middle class & $\begin{array}{c}\text { Incomers; 'localist cosmopolitans' } \\
\text { or 'non-localist spiralists' }\end{array}$ \\
$\begin{array}{l}\text { Retired Urban Workers } \\
\text { with Some Capital }\end{array}$ & Unspecified & Incomers; unspecified relation with locality \\
$\begin{array}{l}\text { Urban Workers with Limited } \\
\text { Capital/Income }\end{array}$ & Working class & Incomers; worked beyond the village \\
$\begin{array}{lll}\text { Rural Working-Class } \\
\text { Commuters }\end{array}$ & Working class & Locals but worked beyond the village \\
\hline \begin{tabular}{l} 
Traditional Ruralites \\
\hline
\end{tabular} & Working class & Local and experientially embedded in the local \\
\hline
\end{tabular}

Source: Based on Pahl (1966).

may have worked against recognition of the specificity of this middle class and, more generally, the presence of such a middle class might suggest that Pahl's research was itself very much bound into a quite specific spatial and historical conjuncture in which the rural gentrification of Hertfordshire was also being constituted.

\section{Contemporary gentrification in rural Hertfordshire}

Analysis of the 2011 Census suggests that the industrial and managerial middle class still formed a significant constituent of the population in rural Hertfordshire (see Figure 4), although Census analysis, questionnaire and fieldwork observations also identified a series of other 'middle-class' residents and different forms of gentrification, as well as illustrated how much of rural Hertfordshire is now occupied by a relatively small number of people with working class occupations that are classified as routine or semi-routine. The new forms of gentrification include what Butler and Lees (2006) identify as 'super-gentrification', which is seen to involve the movement of people with very high incomes into already gentrified areas, and an associated refurbishing or re-building of already gentrified properties.

This form of gentrification appeared to be evident in Tewin Wood, an area of woodland close to the village of Tewin that, as Pahl (2008b: 105-106) records, was part of a large landed estate until 1919, after which it "became available for new house-building", that was clearly in evidence when Pahl undertook his research:

at the time of the survey, the woods echoed to the sound of Tudor beaming being hammered into place, as a firm of North London builders created 'a choice of standard, split level and continental designs in woodland setting'. (Pahl, 1965: 45) 
Figure 4. The distribution of industrialists/managers and other social classes in North and East Hertfordshire, 2011

\section{Managers \&}

industrialists

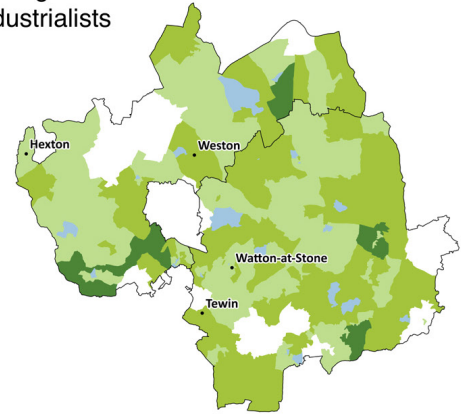

\section{Professionals}

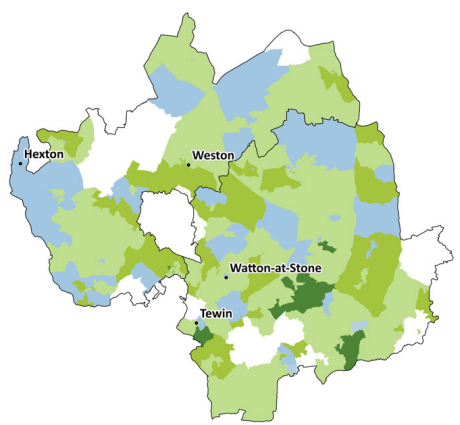

\section{Commercial}

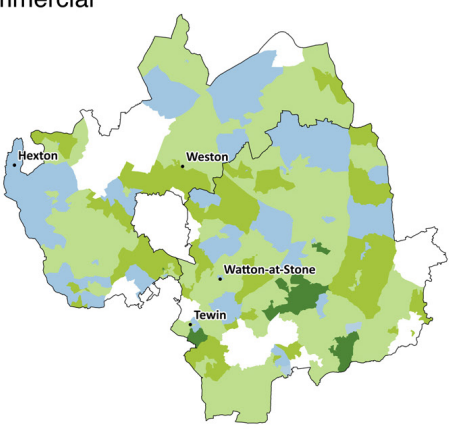

Petit Bourgeois

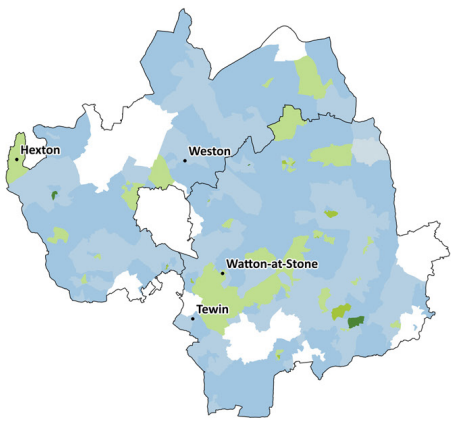

\section{Creative}

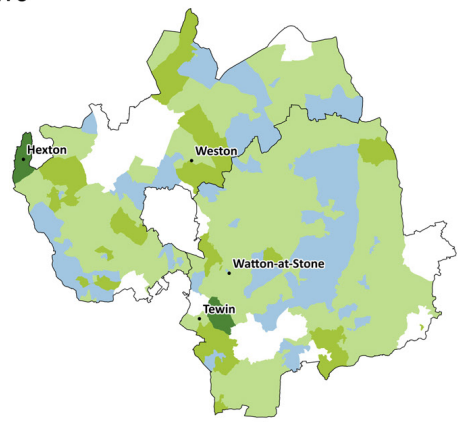

Routine and Semi-Routine

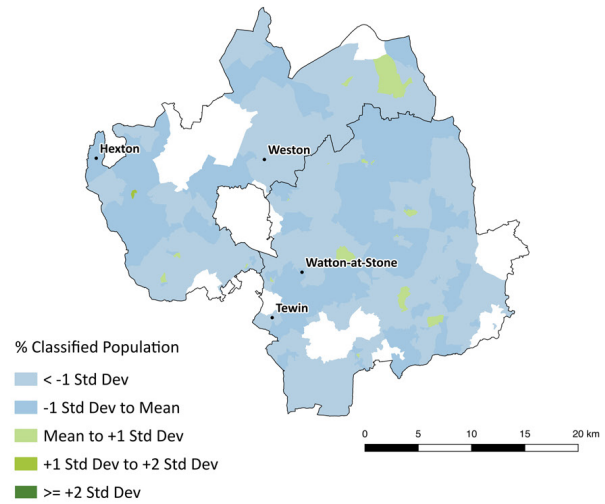

Source: The authors; contains Office for National Statistics (2011): 2011 Census aggregate data (Edition: May 2011). UK Data Service; National Statistics data (C) Crown copyright and database right [2012] and OS data @ Crown copyright [and database right] (2012). 
Figure 5. New housing development in Tewin Wood

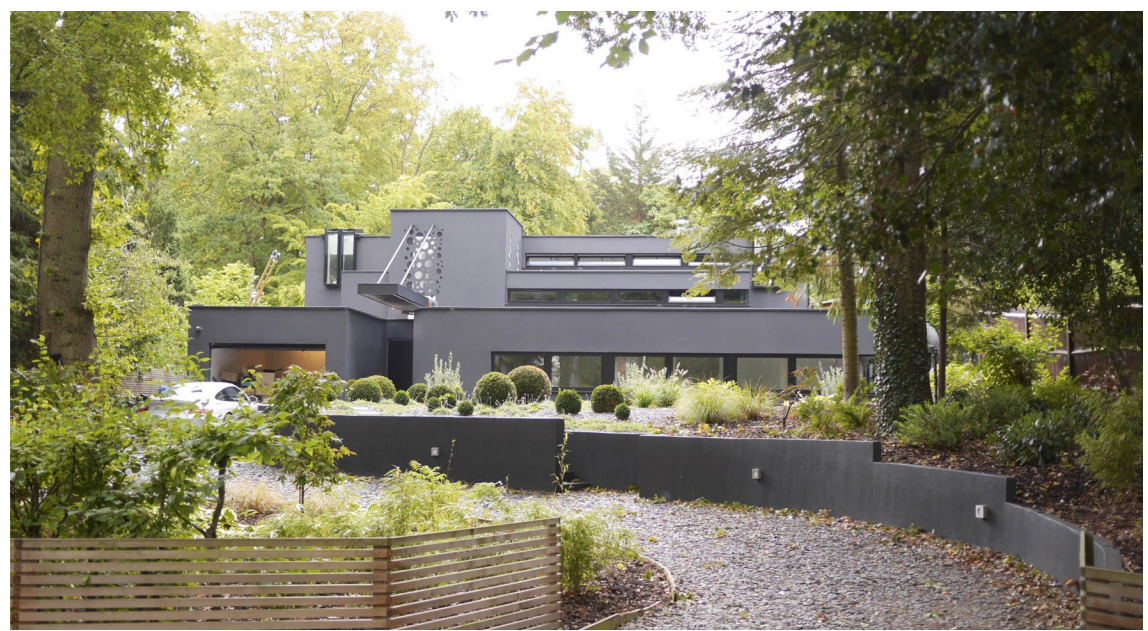

Source: Authors' photograph.

Many mock-Tudor buildings are very much still in evidence in Tewin Wood today, but comments from residents indicated that some had been demolished and much larger buildings constructed in their place (see Figure 5; and also Smith et al., 2018). There were clear expressions of concern about the extent of these new-builds and the social and environmental transformations that were viewed as accompanying them:

in the next 20 years I would predict that every bungalow will be developed $[\ldots]$ it's just becoming a developer's paradise. (Professional employee, software development)

when we moved in, it felt very much that there was a much more natural feel to it. [...] Areas have been cleared where a smaller house has suddenly been replaced by a bigger house or some plots where a whole new house has gone up [...] So it feels like, you know, the human imprint has got much stronger $[\ldots]$ They're trying to recreate that London look here. (Professional employee, IT development)

This is not to say that these changes were the only form of gentrification evident in the villages. There were, for instance, still less affluent people in technical and managerial occupations moving into refurbished or newly built properties, although many of these appeared to be either self-employed 'outsourced' producer service workers, working in their own consultancy businesses, or workers in newly privatised public sector organisations. It was also evident that the movements of many of these producer service workers were influenced by idyllic conceptualisations of living in these rural settlements: 
Figure 6. Redeveloped council housing

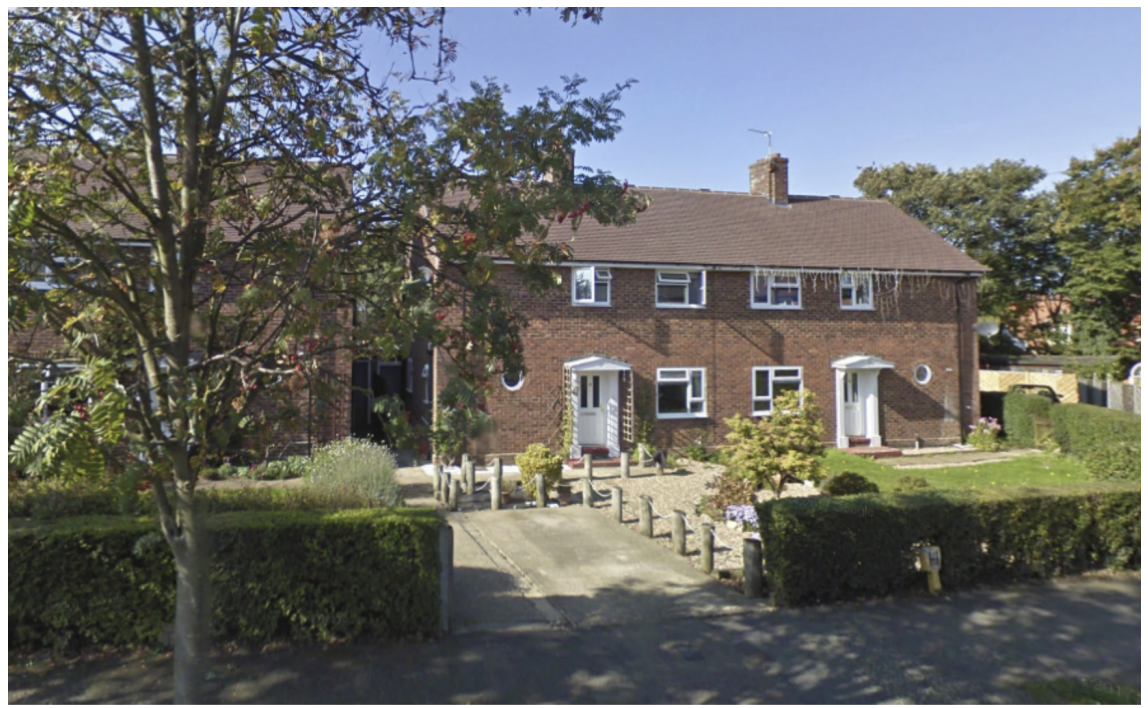

Source: Authors' photograph.

One thing that I do like about here is that, I actually freelance, I work in IT, so one of the things key for me is to be able to live in a peaceful area or enjoyable, quiet area and travel easily into London. (Higher professional, self-employed, information technology and property)

It's a very special place actually [...] we literally came out to it while we were both working in London, so it was a commuter move really [...]. It's that perfect combination of the lovely rural village and we've got the cricket pitch literally outside our back gate. We've got fields, a view of fields from every single window from the house [...] and lots of walks and bicycle routes literally outside every door. Very, very friendly village. Everybody is lovely and friendly. (Higher professional, small employer, digital marketing and branding)

There was also a younger group of workers working in London or in locations around north London who were renting ex-social housing that had been converted into modernised houses of multiple occupation (see Figure 6). These workers did not seem to be investing in owning property or in a 'villagein-the-mind', but were very much urban focused workers who had come to occupy properties in Hertfordshire villages because they were less expensive than flats or apartments in London. These people were, therefore, in a sense 'urban exiles' who had come to reside in a village as a result of a search for more 'affordable' housing. It was clear that areas of social housing were being targeted by housing developers seeking to buy properties to rent to such workers, refurbishing them to both modernise and make them low-maintenance, 
particularly in terms of gardens, which were often given over to the provision of parking spaces for these urban commuters.

As well as considering a range of different agents and forms of gentrification, our research sought to examine the issue of displacement, which, as noted earlier, has been viewed by Halfacree (2018) as absent from both Pahl's work and potentially from the wider British countryside during the period of Pahl's study of Hertfordshire.

\section{Displacement in the past and present Hertfordshire countryside}

As discussed elsewhere (Phillips and Smith, 2018b), we feel that whilst Halfacree is right to highlight questions about the significance of displacement both within rural studies generally and in relation to the potential timing of working class out-migration and middle class in-migration, clear parallels exist with urban studies, and have neither resulted in a widespread reticence to apply the concept of gentrification nor led to the neglect of displacement issues evidenced in rural studies. More specifically, in relation to the study of gentrification in rural Hertfordshire, our research has identified examples where Pahl actually highlighted some quite specific instances of displacement related to the arrival of middle-class residents into the villages he was studying. For instance, in Pahl (1966: 1147) there is reference to 'masked depopulation' where the in-migration of middle-class residents "conceals the emigration of young manual workers". Moreover, his original questionnaires contain comments indicative of individuals being displaced to make way for new residents. In one questionnaire, for instance, there is an entry that one respondent liked living in the village of Tewin,

but was very unhappy to move from farm cottages (condemned) to council house - 'all in a row so you get no privacy'. Felt is a great distance from Upper Green to Tewin when moved. House built on site in Upper Green 'and gentry live there now'. (Employee, routine work, domestic cleaning)

This description of events exhibits many of the classic hallmarks of gentrification, including displacement: a person is made to move away from a property despite wishing to remain, the property is rebuilt and becomes a place of residence for someone seen to be socially different from the earlier resident, and who is even described using the term gentry.

Our more recent study also produced quite direct descriptions of events that seem to bear the hallmarks of gentrification and displacement. So, for example, in one of the villages we studied, one resident remarked that,

The village has changed a lot [...] and not for the good, I'm afraid. A lot of bad things have happened, a lot of my neighbours have basically gone, because they have been 'rack rented'. You might have heard of the term Rachmanism, and I'm not far off this really. The trouble is that London is creeping out, rents are getting higher and higher. (No occupation details given) 
This resident was renting property, and claimed that the local estate owner was increasing rents to the extent that many prior residents felt they could not afford to remain in these properties, and were hence moving out of the village whilst their previous homes were rented out to more affluent households that had previously resided in London. Such processes of displacement through rent increases have been frequently identified within studies of urban gentrification (e.g. Engels, 1999; Newman and Wyly, 2006; Holm, 2013), although in a rural context emphasis has often been placed on escalating house purchase prices (e.g. Shucksmith, 1981, 1991; Liu and Roberts, 2012, 2013). Concerns over rising home purchase prices were also very clearly evidenced, with one resident giving a particularly vivid account of such processes and their consequences:

You don't get many Weston people [...] stopping on here because the houses are so expensive and there's so few council houses that the chances of getting one when you get married are limited [...] we did get tipped off about a bungalow down the road for $£ 3,500[\ldots]$ and between the time that we were tipped off that that was the price and it actually being sold, it sold for $£ 13,000$ [...] you couldn't save enough money to keep up with the prices. (Employee, semi-routine work, retailing)

Both instances can be seen to clearly demonstrate the presence of displacement, although there are significant differences between them. These include tenurial differences: as discussed above, the first relates to rented properties whilst the latter relates to owner-occupation. In addition, the former case relates to the displacement of a person from an existing place of residence, whilst the latter concerns a thwarted attempt to move into a vacant property in the village. Within studies of urban gentrification there has been increasing recognition of diversity in the ways displacement may operate, with the work of Marcuse (1985) being widely employed (e.g. Slater, 2009, 2010; Butler et al., 2013; Davidson, 2008; Davidson and Lees, 2010). Marcuse identified four forms of displacement - direct last-resident displacement, direct chain displacement, exclusionary displacement, and displacement pressure - and material suggestive of each of these surfaced in our research in the three Hertfordshire villages.

\section{Displacement forms in the contemporary gentrified countryside}

The term 'direct last-resident displacement' was coined by Marcuse to refer to combinations of physical force, material neglect and economic pricing which lead to residents relinquishing access to buildings or areas of land, which then become appropriated for gentrification. Material commensurable with Marcuse's conceptualisation of this form of displacement has already been presented. So, for example, the account presented in one of the questionnaires from Pahl's research described a resident having to move from a 'condemned' farm cottage that was demolished and replaced by a house for a member of 
the 'gentry', can be viewed as illustrating direct last-resident displacement. So too, could the remarks expressed within our study by a resident exclaiming that people were leaving the village due to having been 'rack rented', with rents getting "higher and higher" until people felt they could no longer afford to pay them. In this case, properties appear to have been rented out to new residents rather than being sold to incoming owner-occupiers.

The remark from the resident in Weston that people from the village were no longer "stopping on" might also be viewed as indicative of direct lastresident displacement, albeit related to property ownership rather than renting. However, it can also be viewed as indicative of processes that connect to Marcuse's concepts of 'direct chain displacement'. Marcuse coined this phrase to highlight that displacement can involve more than a single instance of movement. As Marcuse notes, it may be that other people may have left a particular property before the final departure before gentrification. Whilst there may not have been any change in the social character of the residents living in the property during these earlier moves, these movements might still warrant consideration as instances of displacement. The quote from the resident in Weston, and the comments of a series of other working-class residents we interviewed, seem to point to the presence of a series of displacements either prior to, or without, direct-last resident displacement. In particular, as illustrated by the following two extracts, there were comments indicating that the off-spring of many working-class rural residents had left the village as a consequence of feeling that they could never access housing within these localities,

the working class people in the village [...] my generation who I went to school with, they couldn't buy a house in Weston; they couldn't afford it [...] and they moved out of the village and they went to like towns and that [...] [T] here's not many of my school friends who live in the village because they got married and moved out, you know, and they couldn't afford to buy a house [...] So, in a way we were driven out. (Higher managerial and administrative employee, purchasing)

I would love to see my daughter come back to the village. I've got about 20-odd nephews and nieces and I would love to see all of them back [...] There needs to be an assortment, not just big all posh houses [...] if the family that have the estate don't really want you to build on your bit of land, they have ways of making sure you don't [...] I know about three instances whereby three people have got three different little plots of land that are not interfering with anybody, and all of them, they had objections put in and were told, no way are you ever going to get planning permission. One of them was my brother. (Employee, semi-routine work, retailing)

As research on rural youth out-migration has highlighted (Jamieson, 2000; Ní Laoire, 2000; Farrugia, 2016), there are a range of reasons why young people move away from rural locations, and consequently it may not always be appropriate to see such moves as indicative of displacement. However, the quotes above suggest that, at least in these instances, there was a desire to 
remain within the village that was not seen to be realisable and it was this that created movement away from the village.

In villages experiencing such chain displacement there may be a continuing 'working class' presence for a long time, but this is not being reproduced into the future, and hence once the parents die or decide to leave the village, their properties may become available for gentrification. As previously noted, there was evidence in one village of the gentrification of former council housing by developers looking to provide rental housing to young professionals, in addition to the more widespread marginal gentrification of such properties as identified by Chaney and Sherwood (2000).

The gentrification of former 'social housing' can be seen to connect to the third form of displacement identified by Marcuse, namely exclusionary displacement, although this concept has relevance across a range of housing forms. Marcuse argued that the gentrification of properties can act to create displacement by preventing the replacement of non-gentrifier householders by other non-gentrifier households. This can occur through potential residents being unable to afford the increased prices or rents of gentrified properties or because these properties do not suit their needs and tastes. There may even, in some instances, not be any direct displacement but there is exclusion of movement into properties by certain social groups, as illustrated in the following two accounts of contemporary housing dynamics:

the way that the property prices are in this area it's almost a self-fulfilling prophecy that it's older people who are purchasing the houses at the moment, or staying in them and not moving. If you look at the moment, you cannot rent a property in this village. There just simply isn't one to rent [...] I couldn't afford to buy somewhere on my own [...] if I had a family unit [...] I think it's a great place to live. I think living on your own here is a 'no', it's not a great place to live if you're looking for social interaction to any degree. (Higher managerial and administrative employee, marketing)

it always tends to be families moving in, young families - people with young families moving in. So, for instance, I haven't seen people who retire move out and then similar aged individuals moving in. It's always [...] younger families moving in. (Professional consultant, IT and property development)

These two quotes both frame housing dynamics in terms of the relationship between available properties and the age profiles of in- and out- migrants, although they focus on two distinct age demographics: older people and young families. As discussed in Smith et al. (2019), there is a need to examine the intersection of age demographics and ageing with processes of rural gentrification.

The final form of displacement identified by Marcuse is displacement pressure, which is seen to occur through the changing character of gentrified places, such that these locations become "less and less liveable" (Marcuse, 1985: 206) for some existing residents. As illustrated in the quotes below, this decline in 
liveability can be very material in form, involving loss of local employment and/or transportation services that allow rural residents to get into work, or indeed access retail and welfare services.

If you haven't got transport for instance, there was nothing you could do, unless you fancied doing somebody's housework for them or working in the village shop, if they've got a vacancy. (Employee, semi-routine work, retailing)

they tried a trial with a community service but if that isn't replaced, this location will be the preserve of the wealthy who can afford private transport. Because if you depend on a bus to get you to the GP which is four miles away, it's not funny really $[\ldots]$ My daughter used to go on it [the bus] to school [...] but they axed it, it just wasn't economical. (Professional employee, software development)

Displacement pressures may also work in more experiential and affective ways, whereby people come to feel that they do not belong to a place or places are changing in ways that do not reflect their values and ways of living. Davidson and Lees (2010: 403) have, for instance, argued that studies need to pay greater attention to the senses of place contained within the notion of "displacement" (original emphasis). Our interviews clearly recorded expressions of people coming to feel 'out of place' within villages undergoing gentrification, as illustrated in the following extracts:

this is where my dislike for the yuppies and such like comes from. I really don't like them moving up here and trying to alter what has been established for generations. Such as, they wanted to knock down our village hall and build a new one $[\ldots]$ They now want to knock down the school to build a new one. I believe in these village things, it's our heritage. It's part of what makes [...] [this village] a nice place to live but they want to change it all. It's not good enough for them. (Employee, semi-routine work, retailing)

It's kind of spoiling the feel of the village because you've got this newness; whereas previously it was all very kind of, you know, quite a mature place $[. .$. It feels a little bit commuter belt-ish. (Professional employee, IT development)

The last quote illustrates that such feelings of displacement were not restricted to working class residents but were also expressed by some gentrifiers who were reacting to subsequent forms of gentrification that appeared to express and produce different practices, values, social relations and rural landscapes to those that emerged within their own gentrification of the village. Recognition of the experiential and affective dimensions of place opens up points of connection to notions of idyllic, and, indeed, non-idyllic, conceptions of rurality and Pahl's differentiation of 'village-in-the-mind'. Pahl's account of Hertfordshire villages presents an image of clear differentiation between the incoming middle-class and working class locals, a dualism, which as noted earlier, he later questioned (Pahl, 2008b). However, with a range of middle, 
and indeed working class, groups co-present in the village, one might expect complex forms of displacement pressure to exist within contemporary villages.

\section{Conclusion}

This paper has sought to highlight how processes of rural gentrification not only connect to notions of idyllic constructions of rurality but also to processes of displacement. The paper has demonstrated connections between the concept of rural idyll and rural gentrification contained in the writings of Ray Pahl, who despite never using these terms in his writings, is widely ascribed to have been a progenitor of both, through his conceptions of 'village-in-the-mind' and concern to document the movement of middle class people into villages in areas around London such as Hertfordshire. The concepts of rural idyll and rural gentrification have both been subject to some critical commentary, although both have continued to exert a considerable influence on rural studies within Europe and beyond. This paper has highlighted some of the divergent ways that the concepts of rural idyll and rural gentrification have been developed, before focusing on arguments that idyllic constructions of rurality foster processes of rural gentrification through the establishment of a sense of the countryside as a desirable location. Particular attention has been paid to the parallels between Halfacree's discussions of the rural idyll and the work of Caulfield on urban gentrification, as they both highlight how the desire for rural living might reflect resistance to aspects of mainstream capitalist society. Halfacree's arguments are, however, tempered by an acknowledgement that expressions of resistance are also frequently conjoined with practices that reinforce class differentials and exclusions; although he also questions the extent to which displacement is of relevance when interpreting the rising presence of middle-class residents in the British countryside. This argument, which Halfacree generates in part by consideration of the work of Pahl on rural Hertfordshire, is of particular significance because displacement has widely been viewed as amongst gentrification's definitive features, and hence the absence of displacement may be viewed as signalling the inappropriateness of applying the concept gentrification to rural contexts.

In this paper we have explored the significance of idyllic interpretations of rurality in the movement of middle-class residents to rural Hertfordshire, drawing both on Pahl's original research and a contemporary 'multi-method' questionnaire in three of the four villages that were studied by Pahl. We argue that these villages were experiencing in-migration particularly by a technocratic and managerial middle class at the point when they were studied by Pahl and subsequently, with many of these in-migrants clearly expressing idyllic conceptions of rurality. We suggest that Pahl did not recognise the specificities of these middle-class migrants in part perhaps because of his experiential proximity to this middle class, while our contemporary research highlighted the reconfiguration of this class through the rising presence of consultancies and privatised public sector providers. The contemporary research also indicated that 
there were a range of distinct forms of gentrification present within the three Hertfordshire villages. These included 'super-gentrification' in Tewin Wood, whereby households with very high incomes were moving into properties that had already been constructed for middle-class residents and were refurbishing or re-building them to form much larger, luxurious dwellings, and also elsewhere, an 'urban exile' form of gentrification whereby young urban commuters were moving into former social housing that had been converted into modernised houses of multiple occupation. It was suggested that these workers were locating in the villages largely because they offered affordable property rather than an idyllic rural location, thereby highlighting that not all forms of rural gentrification in these villages were constituted through a variant of the rural idyll.

As well as examining forms of rural gentrification and the significance of idyllic conceptions of rurality within the movement of gentrifiers to these three Hertfordshire villages, this paper has also considered the operation of displacement in these settlements. The presence of a range of forms of gentrification and types of gentrifiers raises important questions about displacement, as these new groups may come to occupy buildings or spaces previously occupied by working-class residents or indeed, as in Tewin Wood, middle-class residents, in addition to occupying new build developments on former 'greenfield' areas. However, drawing on the concepts of displacement advanced by Marcuse (1985), our research has highlighted the presence of displacement not only in the contemporary Hertfordshire countryside, but also in the rural worlds examined in the 1960s by Ray Pahl. It has also demonstrated that this displacement can range from quite direct forms related to poor housing conditions and escalating rents and property prices, through to displacements that occur over extended periods of time and the denial of opportunities of class replacement, and including the production through gentrification of places that become materially and experientially less liveable for non-gentrifiers, and indeed potentially for some earlier gentrifiers.

\section{Bibliographical references}

Bell, David (1997). “Anti-idyll: rural horror”. In: Cloke, Paul and LitTle, Jo (eds.). Contested Countryside Cultures: Otherness, Marginalisation and Rurality. London: Routledge, 94-108.

Benson, Michelle and Osbaldiston, Nick (eds.) (2014). Understanding Lifestyle Migration: Theoretical Approaches to Migration and the Quest for a Better Way of Life. Basingstoke: Palgrave Macmillan.

Bijker, Rixt Anke and HaArtsen, Tialda (2012). "More than counter-urbanisation: migration to popular and less-popular rural areas in the Netherlands". Population, Space and Place, 18, 643-657. <https://doi.org/10.1002/psp.687>

Bradley, Tony; Lowe, Philip and Wright, Susan (1986). "Introduction: rural deprivation and the welfare transition". In: Lowe, Philip; Bradley, Tony and Wright, Susan (eds.). Deprivation and Welfare in Rural Areas. Norwich: GeoBooks, 1-39. ButLer, Tim (1997). Gentrification and the Middle Classes. Aldershot: Ashgate. 
Butler, Tim; Hamnett, Chris and Ramsden, Mark (2013). "Gentrification, education and exclusionary displacement in East London". International Journal of Urban and Regional Research, 37 (2), 556-575. <https://doi.org/10.1111/1468-2427.12001>

Butler, Tim and LeEs, Loretta (2006). "Super-gentrification in Barnsbury, London: globalisation and gentrifying global elites at the neighbourhood level". Transactions of the Institute of British Geographers, 31 (4), 467-487. <https://doi.org/10.1111/j.1475-5661.2006.00220.x>

Caulfield, Jon (1992). "Gentrification and familism in Toronto: a critique of conventional wisdom". City and Society, 6 (1), 76-89. <https://doi.org/10.1525/city.1992.6.1.76>

- (1994). City Form and Everyday Life: Toronto's Gentrification and Critical Social Practice. Toronto: University of Toronto Press.

Chaney, Paul and Sherwood, Ken (2000). "The resale of right to buy dwellings: a case study of migration and social change in rural England". Journal of Rural Studies, 16 (1), 79-94. <https://doi.org/10.1016/S0743-0167(99)00019-4>

Clark, Eric (2005). "The order and simplicity of gentrification - a political challenge". In: Atkinson, Rowan and Bridge, Gary (eds.). Gentrification in a Global Context: The New Urban Colonialism. London: Routledge, 256-264.

Cloke, Paul (1979). Key Settlements in Rural Areas. London: Methuen.

- (2006). "Conceptualizing rurality". In: Cloke, Paul; Marsden, Terry and Mooney, Patrick (eds.). The Handbook of Rural Studies. London: Sage, 18-28.

Cloke, Paul and Thrift, Nigel (1987). "Intra-class conflict in rural areas". Journal of Rural Studies, 3 (4), 321-333.

<https://doi.org/10.1016/0743-0167(87)90051-9>

Cortes-VAzquez, Jose (2017). "The end of the idyll? Post-crisis conservation and amenity migration in natural protected areas". Journal of Rural Studies, 51, 115-124. <http://dx.doi.org/10.1016/j.jrurstud.2017.02.005>

DA Silva, Diogo Soares; Figueiredo, Elisabete; Eusebio, Celeste and Carneiro, João (2016). "The countryside is worth a thousand words: Portuguese representations on rural areas". Journal of Rural Studies, 44, 77-88. <https://doi.org/10.1016/j.jrurstud.2016.01.012>

Davidson, Mark (2008). "Spoiled mixture: where does state-led 'positive' gentrification end?" Urban Studies, 45 (12), 2385-2405. <https://doi.org/10.1177/0042098008097105>

DAvidson, Mark and LeEs, Loretta (2005). “New-build 'gentrification' and London's riverside renaissance”. Environment and Planning A, 37 (7), 1165-1190. $<$ https://doi.org/10.1068/a3739>

- (2010). "New-build gentrification: its histories, trajectories, and critical geographies". Population, Space and Place, 16 (5), 395-411. <https://doi.org/10.1002/psp.584>

Elliott-Cooper, Adam; Hubbard, Phil and Lees, Loretta (2019). "Moving beyond Marcuse: gentrification, displacement and the violence of un-homing". Progress in Human Geography. <https://doi.org/10.1177/0309132519830511>

Engels, Benno (1999). "Property ownership, tenure, and displacement: in search of the process of gentrification". Environment and Planning A, 31, 1473-1495. <https://doi.org/10.1068/a311473> 
FARrugia, David (2016). "The mobility imperative for rural youth: the structural, symbolic and non-representational dimensions rural youth mobilities". Journal of Youth Studies, 19 (6), 836-851. <https://doi.org/10.1080/13676261.2015.1112886>

Gallent, Nick (2011). "Gentrification and the discourses of housing affordability, localness and priority in rural England". Planning Theory and Practice, 12 (4), 611-618. <https://doi.org/10.1080/14649357.2011.626304>

Glass, Ruth (1964). "Aspects of change”. In: Centre for Urban Studies (ed.). London: Aspects of Change. London: MacGibbon and Kee, xiii-xlii.

Halfacree, Keith (1994). "The importance of 'the rural' in the constitution of counterurbanization: evidence from England in the 1980s". Sociologia Ruralis, XXXIV (2-3), 164-189.

<https://doi.org/10.1111/j.1467-9523.1994.tb00807.x>

- (1995). Talking about rurality: social representations of the rural as expressed by residents of six English parishes. Journal of Rural Studies, 11 (1), 1-20. <https://doi.org/10.1016/0743-0167(94)00039-C>

- (2007). "Trial by space for a 'radical rural': introducing alternative localities, representations and lives". Journal of Rural Studies, 23 (2), 125-141. <https://doi.org/10.1016/j.jrurstud.2006.10.002>

- (2010). "Reading rural consumption practices for difference: boltholes, castles and life-rafts". Culture Unbound, 2 (2), 241-263. <https://doi.org/10.3384/cu.2000.1525.10214241>

- (2011). "Radical spaces of rural gentrification". Planning Theory and Practice, 12 (4), 618-625. <https://doi.org/10.1080/14649357.2011.626304>

- (2018). "From Ambridge to the world? Class returns to rural population geographies". Dialogues in Human Geography, 8 (1), 26-30. <https://doi.org/10.1177/2043820617752003>

Halfacree, Keith and Rivera, María Jesús (2012). "Moving to the countryside ... and staying: lives beyond representations". Sociologia Ruralis, 52 (1), 92-114. <https://doi.org/10.1111/j.1467-9523.2011.00556.x>

Hamnett, Chris (1991). "The blind men and the elephant: the explanation of gentrification". Transactions of the Institute of British Geographers, 16 (2), 173-189. <https://doi.org/10.2307/622612>

- (1992). "Gentrifiers or lemmings? A response to Neil Smith". Transactions of the Institute of British Geographers, 17 (1), 116-119. $<$ https://doi.org/10.2307/622642>

- (2009). "The new Mikado? Tom Slater, gentrification and displacement". City, 13 (4), 476-482. <https://doi.org/10.1080/13604810903298672>

- (2010). “I am critical. You are mainstream': a response to Slater”. City, 14 (1-2), 80-186. <https://doi.org/10.1080/13604810903579287>

HJort, Susanne and Malmberg, Gunnar (2006). "The attraction of the rural: characteristics of rural migrants in Sweden”. Scottish Geographical Journal, 122, 55-75. <https://doi.org/10.1080/00369220600830870>

HoggarT, Keith (2005). "Inequalities at the core: a discussion of regionality in the EU and UK”. In: Phillips, Martin (ed.). Contested Worlds: An Introduction to Human Geography. Aldershot: Ashgate, 191-227. 
Holm, Andrej (2013). “Berlin's gentrification mainstream”. In: Bernt, Matthias; Grell, Britta and Holm, Andrej (eds.). The Berlin Reader: A Compendium on Urban Change and Activism. Bielefeld: Transcript-Verlag, 171-188.

Horton, John (2008). "Producing Postman Pat: the popular cultural construction of idyllic rurality". Journal of Rural Studies, 24, 389-398. <https:// doi.org/10.1016/j.jrurstud.2008.03.011>

James, Sarah (1991). The Urban-Rural Myth - Or Reality? Reading: Department of Geography, Reading University.

JAMieson, Lynn (2000). "Migration, place and class: youth in a rural area". Sociological Review, 48 (2), 203-223. <https://doi.org/10.1111/1467-954X.00212>

Kerrigan, Nathan Aaron (2018). A Threatened Rural Idyll? Informal Social Control, Exclusion and the Resistance to Change in the English Countryside. Wilmington, Delaware: Vernon Press.

KeY, Wesley (2014). “Ageing in rural communities: from idyll to exclusion?” In: Bosworth, Gary and Somerville, Peter (eds.). Interpreting Rurality: Multi-Disciplinary Approaches. London: Routledge, 251-266.

LEES, Loretta (2000). "A reappraisal of gentrification: towards a 'geography of gentrification”". Progress in Human Geography, 24 (3), 389-408. <https://doi.org/10.1191/030913200701540483>

LeEs, Loretta; Slater, Tom and Wyly, Elvin (2008). Gentrification. London: Routledge. LeY, David (1996). The New Middle Classes and the Remaking of the Central City. Oxford: Oxford University Press.

Liu, Nan and Roberts, Deborah (2012). "Do incomers pay more for rural housing?" Environment and Planning A, 44, 1986-2005. <https://doi.org/10.1068/a44495>

- (2013). "Counter-urbanisation, planning and house prices: an analysis of the Aberdeen housing market area, 1984-2010”. Town Planning Review, 84 (1), 81-105. <https://doi.org/10.3828/tpr.2013.5>

Marcuse, Peter (1985). "Gentrification, abandonment and displacement: connections, causes and policy responses in New York City". Journal of Urban and Contemporary Law, 28 (1), 195-240.

McGuirk, Pauline and O'Neill, Phillip (2016). "Using questionnaires in qualitative human geography". In: Hay, Iain (ed.). Qualitative Research Methods in Human Geography. Oxford: Oxford University Press, 246-273.

McLaughlin, Brian (1986). "Rural policy in the 1980s: the revival of the rural idyll". Journal of Rural Studies, 2 (2), 81-90. <https://doi.org/10.1016/0743-0167(86)90047-1>

Nelson, Peter and Hines, Dwight (2018). "Rural gentrification and networks of capital accumulation: a case study of Jackson, Wyoming”. Environment and Planning $A, 50,1473-1495$.

<https://doi.org/10.1177/0308518X18778595>

Newby, Howard and Buttel, Frederick (1980). "Towards a critical rural sociology". In: Buttel, Frederick and Newby, Howard (eds.). The Rural Sociology of Advanced Societies: Critical Perspectives. London: Croom Helm, 1-35.

NEWMAN, Kathe and WYLY, Elvin (2006). "The right to stay put, revisited: gentrification and resistance to displacement in New York City”. Urban Studies, 43 (1), 23-57. <https://doi.org/10.1080/00420980500388710> 
Ní LaOire, Caitriona (2000). "Conceptualising Irish rural youth migration: a biographical approach". International Journal of Population Geography, 6 (3), 229-243. <https://doi.org/10.1002/1099-1220(200005/06)6:3<229::AID-IJPG185> 3.0.CO;2-R>

PaHL, Ray (1964). "The two class village". New Society, 27 (7), 7-9.

- (1965a). "Class and community in English commuter villages". Sociologia Ruralis, $5,5-23$.

<https://doi.org/10.1111/j.1467-9523.1965.tb00507.x>

- (1965b). Urbs in Rure: The Metropolitan Fringe in Hertfordshire. London: London School of Economics.

- (1966). "The rural-urban continuum". Sociologia Ruralis, 6, 299-327. <https://doi.org/10.1111/j.1467-9523.1966.tb00537.x>

- (2005). "Are all communities communities in the mind?" The Sociological Review, 53 (4), 621-640. <https://doi.org/10.1111/j.1467-954X.2005.00587.x>

- (2008a). "Have personal communities replaced geographical communities?", Eila Campbell Lecture, Department of Geography, Environment and Development Studies, Birkbeck College, University of London <http://www.bbk.ac.uk/geography/news-and-events/events-old/eila-campbell-lectures/have-personal-communities-replaced-geographical-communities >; accessed 18/2/19.

- (2008b). "Hertfordshire commuter villages: from Geography to Sociology". International Journal of Social Research Methodology, 11 (2), 103-107. <https://doi.org/10.1080/13645570801940772>

- (2018). Three Hertfordshire Villages Survey, 1961. [data collection]. UK Data Service. SN: 853320.

<http://doi.org/10.5255/UKDA-SN-853320>

PARIS, Chris (2008). "Re-positioning second homes within housing studies: household investment, gentrification, multiple residence, mobility and hyper-consumption". Housing, Theory and Society, 26 (4), 292-310. <https://doi.org/10.1080/14036090802300392>

Parsons, David (1980). Rural Gentrification: The Influence of Rural Settlement Planning Policies. Brighton: Department of Geography, University of Sussex.

Peeren, Esther and Souch, Irina (2019). "Romance in the cowshed: challenging and reaffirming the rural idyll in the Dutch reality TV show Farmer Wants a Wife". Journal of Rural Studies, 67, 37-45. <https://doi.org/10.1016/j.jrurstud.2019.02.001>

Phillips, Martin (1994). "Habermas, rural studies and critical social theory". In: Cloke, Paul; Doel, Marcus; Matless, David; Phillips, Martin and Thrift, Nigel (eds.). Writing the Rural: Five Cultural Geographies. London: Paul Chapman, 89-126.

- (1998). "The restructuring of social imaginations in rural geography". Journal of Rural Studies, 18 (2), 121-153. <https://doi.org/10.1016/S0743-0167(97)00056-9>

- (2005). "Differential productions of rural gentrification: illustrations from North and South Norfolk". Geoforum, 36 (4), 477-494. <https://doi.org/10.1016/j.geoforum.2004.08.001>

- 2010) "Rural gentrification and the built environment: exploring the connections". In: Gellner, Paul (ed.). Built Environment: Design, Management and Applications. Hauppauge, New York: Nova Publishers, 33-61. 
Phillips, Martin; Fish, Rob and AgG, Jennifer (2001). "Putting together ruralities: towards a symbolic analysis of rurality in the British mass media". Journal of Rural Studies, 17 (1), 1-27. <https://doi.org/10.1016/S0743-0167(00)00015-2>

Phillips, Martin and Smith, Darren (2018a). "Comparative approaches to gentrification: lessons from the rural". Dialogues in Human Geography, 8 (1), 3-25. <https://doi.org/10.1177/2043820617752009>

- (2018b). "Comparative ruralism and 'opening new windows' on gentrification". Dialogues in Human Geography, 8 (1), 51-58. <https://doi.org/10.1177/2043820617752035>

Rye, John (2006). "Rural youths' images of the rural”. Journal of Rural Studies, 25 (4), 409-421. <https://doi.org/10.1016/j.jrurstud.2006.01.005>

Savage, Mike (2010). Identities and Social Change in Britain since 1940. Oxford: Oxford University Press.

Shucksmith, Mark (1981). No Homes for Locals? Farnborough: Gower Press.

- (1991). "Still no homes for local? Affordable housing and planning controls in rural areas". In: Champion, Tony and Watkins, Charles (eds.) People in the Countryside: Studies of Social Change in Rural Britain. London: Paul Chapman, 53-66.

- (2016). "Re-imagining the rural: from rural idyll to good countryside". Journal of Rural Studies, 59, 163-172. <https://doi.org/10.1016/j.jrurstud.2016.07.019>

Slater, Tom (2004). "North American gentrification? Revanchist and emancipatory perspectives explored”. Environment and Planning A, 36 (7), 1191-1213. <https://doi.org/10.1068/a368>

- (2006). "The eviction of critical perspectives from gentrification research". International Journal of Urban and Regional Research, 30 (4), 737-757. <https://doi.org/10.1111/j.1468-2427.2006.00689.x>

- (2008). "'A literal necessity to be re-placed': a rejoinder to the gentrification debate". International Journal of Urban and Regional Research 32 (1), 212-223. <https://doi.org/10.1111/j.1468-2427.2008.00781.x>

- (2009). "Missing Marcuse: on gentrification and displacement". City, 13 (2-3), 292-311. $<$ https://doi.org/10.1080/13604810902982250>

- (2010). "Still missing Marcuse: Hamnett's foggy analysis in London town". City, 14 (1-2), 170-179. <https://doi.org/10.1080/13604811003633719>

Smith, Darren and Phillips, Deborah (2001). "Socio-cultural representations of greentrified Pennine rurality”. Journal of Rural Studies, 17 (4), 457-469. <https://doi.org/10.1016/S0743-0167(01)00014-6>

Smith, Darren; Phillips, Martin and Kinton, Chloe (2018). "Wilderness gentrification: moving 'off-the-beaten rural tracks'". In: LeEs, Loretta and PHILlips, Martin (eds.). Handbook of Gentrification Studies. Cheltenham: Edward Elgar, 363-391.

Smith, Darren; Phillips, Martin; Brooking, Hannah; Duer, Mara and Kinton, Chloe (2019). "The dynamics of rural gentrification and the effects of ageing on gentrified rural places". Ager, 27, 129-157.

<https://doi.org/10.4422/ager.2019.13> 
Smith, Darren; Phillips, Martin; Kinton, Chloe and Culora, Andreas (2019). "Rural population geographies in the differential countryside?". In: Sсотт, Mark; Gallent, Nick and Gkartzios, Menelaos (eds.). Routledge Companion to Rural Planning. London: Routledge, 239-260.

Smith, Neil (1992). "Blind man's bluff, or Hamnett's philosophical individualism in search of gentrification". Transactions of the Institute of British Geographers, 17 (1), 110-115. <https://doi.org/10.2307/622641>

- (2002). "New globalism, new urbanism: gentrification as global urban strategy". Antipode, 34 (3), 428-450. <https://doi.org/10.1111/1467-8330.00249>

Solana-Solana, Miguel (2010). "Rural gentrification in Catalonia, Spain: a case study of migration, social change and conflicts in the Empordanet area". Geoforum, 41, 508-517. <https://doi.org/10.1016/j.geoforum.2010.01.005>

van Dam, Frank; Heins, Saskia and Elbersen, Berien (2002). "Lay discourses of the rural and stated and revealed preferences for rural living. Some evidence of the existence of a rural idyll in the Netherlands". Journal of Rural Studies, 18 (4), 461-476. <https://doi.org/10.1016/S0743-0167(02)00035-9>

Vepsäläinen, Mia and Pitkänen, Kati (2010). "Second home countryside: representations of the rural in Finnish popular discourses". Journal of Rural Studies, 26 (2), 194-204. <https://doi.org/10.1016/j.jrurstud.2009.07.002>

Woods, Michael (2010). "Performing rurality and practising rural geography". Progress in Human Geography, 34 (6), 835-846. <https://doi.org/10.1177/0309132509357356>

Woodward, Rachel (1996). “'Deprivation' and 'the rural': an investigation into contradictory discourses”. Journal of Rural Studies, 12 (1), 55-67. <https://doi.org/10.1016/0743-0167(95)00048-8> 